\title{
Paulina Ucieklak-Jeż
}

Akademia im. Jana Długosza w Częstochowie

Wydział Filologiczno-Historyczny

p.ucieklak@o2.pl

\section{Agnieszka Bem}

Uniwersytet Ekonomiczny we Wrocławiu

Katedra Finansów Przedsiębiorstw i Finansów Publicznych

agnieszka.bem@ue.wroc.pl

\section{Aktywność fizyczna determinantą zdrowia populacji}

Artykuł nadesłany: 31 maja 2017 r.; artykuł zaakceptowany: 15 grudnia 2017 r.

JEL Classification: I10, I12

Keywords: physical activity, healthy adults, social determinants of health (SHD)

\begin{abstract}
Physical activity as a determinant of population's health status

In this paper we verified and analysed the relationship between: (1) cycling (in minutes) and doing another sports, in a typical week, and social determinants of health; (2) moving on foot in public space and social determinants of health; (3) physical activity associated with the performance of work and the social determinants of health; (4) physical activity and health assessment, long-term health problems, diseases and chronic ailments, and athleticism. We constructed three research hypotheses: (H1) residents of densely populated areas (large cities) are physically active; (H2) the longer the time average intensity of physical activity, the healthier the population; (H3) the healthiest group are people physically active. The first hypothesis was positively verified - inhabitants of large cities often spend a lot of time at work, are stressed and need some physical activity. The second hypothesis was confirmed only partially: Chi square $=1692,469 ;$ Yul $\varphi=0,322$; Q-Kendal$\mathrm{la}=0,297$ indicate that there is a statistically significant relationship between the amount of time spent on sports and health. The longer time spent on sport, the better health. The third hypothesis was also confirmed - active physical enjoy better health.
\end{abstract}


Systematyczny trening nie tylko może przedlużyć dtugość życia, lecz także , dodaje życia do lat”.

\section{Wprowadzenie}

Swoje zdrowie traktujemy jako przedmiot działania systemu, nie doceniając wpływu, jaki może mieć na nie aktywność fizyczna, będąca w istocie nieodłączną częścią zdrowego stylu życia i jednym z aspektów społecznych determinantów zdrowia (dalej: SDH) (Ucieklak-Jeż 2016a, 2016b). Szereg badań potwierdził związek pomiędzy regularną aktywnością fizyczną a zmniejszonym ryzykiem chorób cywilizacyjnych, przede wszystkim chorób serca, nadciśnienia, udaru, cukrzycy typu II, nowotworów (Warburton et al. 2010; Cuesta, Calle 2013; Roux et al. 2008; Uijtdewilligen et al. 2015; Sari 2011; Lee 1993; Slater, Tiggemann 2011; Eime, Young 2013; Dalton et al. 2015; Inoue et al. 2008; Bucksch, Schlicht 2006; Brown, Burton, Rowan 2007). Co więcej, przy małej aktywności fizycznej — poprzez zwiększenie ryzyka chorób przewlekłych — zwiększa się zagrożenie niepełnosprawnością (Milne et al. 2014).

Zgodnie z literaturą tematu tygodniowy czas aktywności fizycznej o średniej intensywności, która prowadzi do obniżonego ryzyka chorób, to 150 minut lub 75 minut aktywności o wysokiej intensywności (Hunter et al. 2015). Po takim czasie zmniejszają się również symptomy niepokoju i depresji (Hernández, Pascual 2013) i następuje poprawa stanu zdrowia psychicznego (Dalton et al. 2015). Jako zadowalającą aktywność fizyczną w czasie wolnym od pracy przyjęto — zgodnie z aktualnymi zaleceniami większości komitetów ekspertów - wykonywanie ćwiczeń fizycznych trwających przynajmniej 30 minut przez większość dni tygodnia (Drygas et al. 2005). Dodatkowe 20 minut aktywności dziennie, w wypadku osób nieaktywnych, zmniejsza liczbę dni po przebytej chorobie w szpitalu o $0,09-0,22$ dnia w roku, co oznacza ograniczenie hospitalizacji na poziomie kilku procent (Sari 2011).

Aktywność fizyczna jest ważna we wszystkich grupach wiekowych, a szczególnie dla młodych kobiet, które w trzeciej dekadzie życia zazwyczaj redukują ją, najczęściej w związku z małżeństwem i macierzyństwem (Uijtdewilligen et al. 2015; Hanlon, Morris, Nabbs 2010). Uprawianie sportu w średnim wieku jest związane z obniżeniem wskaźnika przedwczesnej umieralności i mniejszym ryzykiem rozwoju chorób przewlekłych w podeszłym wieku (Hernández, Pascual 2013). Istotna jest też regularność aktywnego wysiłku fizycznego. Wpływ regularnej aktywności fizycznej u osób w średnim i starszym wieku na przedwczesną umie-

${ }^{1}$ Drygas, Jegier 2003, s. 76-84. Prof. J.N. Morris jedną ze swoich najnowszych prac zatytułowat: Exercise: Todays best buy in public health. 
ralność jest większy w przypadku kobiet, i to niezależnie od formy aktywności i innych czynników zdrowia (Inoue et al. 2008). Badania wykazały, że regularna aktywność fizyczna u kobiet w średnim wieku przynosi znaczące korzyści w zakresie poprawy jakości życia, a więc również stanu zdrowia. Co istotne, większa intestywność ćwiczeń przekłada się na lepsze wyniki w badaniu stanu zdrowia (Rodríguez-Fuentes et al. 2014; Gremeaux et al. 2012). Uprawianie sportu już od najmłodszych lat daje duże prawdopodobieństwo dobrego stanu zdrowia, a efekt ten występuje niezależnie od wieku, płci czy statusu ekonomiczno-społecznego (Dalton et al. 2015).

Wśród zachowań związanych ze zdrowiem można wyróżnić cztery grupy: odnoszące się przede wszystkim do zdrowia fizycznego, psychospołecznego, prewencji i niepodejmowania zachowań ryzykownych. Do zachowań związanych głównie ze zdrowiem fizycznym należą dbałość o ciało i najbliższe otoczenie, aktywność fizyczna, racjonalne żywienie, hartowanie się oraz sen — odpowiedni czas jego trwania i jakość. Natomiast zachowania związane przede wszystkim ze zdrowiem psychospołecznym to korzystanie i dawanie wsparcia społecznego, a także unikanie nadmiaru stresów oraz radzenie sobie z problemami i stresem (Ostrowska 1999).Zwiększony poziom aktywności fizycznej w czasie wolnym jest często domeną osób o wyższym statusie społeczno-ekonomicznym. Podejmowany wysiłek fizyczny może przyczynić się również do uzupełnienia niedoboru ruchu w innych obszarach życia, między innymi w przypadku umysłowej pracy zawodowej (Puciato, Rozpara 2013).

Kobiety podczas badań ankietowych zgłaszają zwykle mniejszą aktywność fizyczną — każdego typu — niż mężczyźni; ponadto poziom aktywności wśród osób dorosłych gwałtownie spada wraz z wiekiem (Lee 1993; Slater, Tiggemann 2011; Evenson 2002; Simons et al. 2015; Ucieklak-Jeż, Bem 2015).

Istotnym czynnikiem warunkującym stan zdrowia osób dorosłych jest styl życia. Rozpoznanymi czynnikami ryzyka, według Wiktorii Wróblewskiej (2010), są: palenie papierosów, konsumpcja alkoholu, niewłaściwa dieta, nadwaga, niewystarczająca ilość snu, mała aktywność fizyczna lub jej brak (Cockerham 2000; McFadden et al. 2008; Svedberg, Bardage 2006; Wróblewska, 2002; Broszkiewicz, Drygas 2016). Od dawna w Europejskim Ankietowym Badaniu Zdrowia (EHIS - European Health Interview Survey) można znaleźć ocenę czyników ryzyka, natomiast w 2014 roku w kwestionariuszu po raz pierwszy znalazł się wachlarz pytań dotyczących trzech rodzajów aktywności fizycznej.

Celem niniejszego artykułu było oszacowanie grupy społecznej, która najczęściej i najintensywniej uprawia sport w Polsce; ponadto zbadanie zależności pomiędzy poziomem aktywności fizycznej a pozostałymi determinantami zdrowia (SDH), a także sprawdzenie zależności poziomu aktywności fizycznej dorosłych mieszkańców Polski i cech subiektywnego stanu zdrowia (ocena stanu zdrowia, długotrwałe problemy zdrowotne, choroby i dolegliwości przewlekłe, sprawność). 
W toku pracy postawiono trzy hipotezy badawcze, które poddano weryfikacji w badaniach:

— H1: mieszkańcy obszarów gęsto zaludnionych (dużych miast) są aktywni fizycznie;

— H2: im dłuższy czas średniej intensywności aktywności fizycznej, tym zdrowsza populacja;

- H3: najzdrowszą grupą społeczną są osoby aktywne fizycznie.

Opierając się na wcześniejszych badaniach, założono, że prawidłowa aktywność fizyczna to średnio intensywne działania w ruchu, które w typowym tygodniu trwają 150 minut lub dłużej, prowadzące do obniżenia długotrwałych problemów zdrowotnych, dolegliwości przewlekłych, zmierzające do poprawy sprawności.

\section{Metodologia badań}

Analizę opracowano na podstawie ostatniego Europejskiego Ankietowego Badania Zdrowia, przeprowadzonego w Polsce w 2014 roku² przez Główny Urząd Statystyczny, a opublikowanego w 2016 roku. W analizowanym badaniu wprowadzono pytania dotyczące trzech rodzajów aktywności fizycznej (GUS 2016), to jest związanej z:

1. uprawianiem sportu, fitnessu, ćwiczeniami na siłowni w czasie wolnym;

2. przemieszczaniem się, docieraniem do różnych miejsc i powrotem zarówno pieszo, jak i na rowerze;

3. głównym zajęciem wykonywanym w życiu codziennym — dla osób pracujących była to aktywność wynikająca ze specyfiki pracy zawodowej, dla innych główne zajęcie (na przykład w przypadku uczniów — zadania wykonywane w ramach nauki, dla niepracujących i emerytów — prowadzenie domu, opieka nad dziećmi i członkami rodziny, a dla bezrobotnych — poszukiwanie pracy i obowiązki domowe).

Społeczne determinanty zdrowia (SDH), które będą analizowne w celu weryfikacji hipotez badawczych, przedstawiono w tabeli 1 .

2 Objętego regulacją prawną UE — Rozporządzeniem Parlamentu Europejskiego i Rady w sprawie statystyk Wspólnoty w zakresie zdrowia publicznego oraz zdrowia i bezpieczeństwa w pracy zgodnie z wytycznymi (Rozporządzenie Komisji UE nr 328/2011 z dnia 5 kwietnia 2011 r.). 
Tabela 1. Społeczne determinanty zdrowia (SDH) zatosowane do oceny aktywności fizycznej

\begin{tabular}{l|l}
\hline \multicolumn{1}{c|}{$\begin{array}{c}\text { Spoleczne determinanty } \\
\text { zdrowia }\end{array}$} & \multicolumn{1}{c}{ Skala } \\
\hline $\mathbf{U}$ - stopień urbanizacji & $\begin{array}{l}\text { obszar gęsto zaludniony, obszar średnio zaludniony, obszar } \\
\text { rzadko zaludniony }\end{array}$ \\
\hline $\mathbf{W}$ - poziom wykształcenia & $\begin{array}{l}\text { wyższe, policealne, średnie, zasadnicze zawodowe, gimnazjalne, } \\
\text { podstawowe, bez wykształcenia }\end{array}$ \\
\hline SC - stan cywilny faktyczny & żyjący w związku, nieżyjący w związku \\
\hline $\mathbf{R}$ - status na rynku pracy & pracujący, bezrobotni, bierni zawodowo \\
\hline $\mathbf{D}$ - dochód ekwiwalentny & $\begin{array}{l}\text { I grupa kwintylowa, II grupa kwintylowa, III grupa } \\
\text { kwintylowa, IV grupa kwintylowa, V grupa kwintylowa }\end{array}$ \\
\hline
\end{tabular}

Źródło: opracowanie własne.

Analizując zależności zdrowotności od społecznych determinantów zdrowia (SDH), obliczono miernik i oparte na nim współczynniki $\varphi$ Yula’a i Q-Kendell.

Z uwagi na to, że dane z badania EHIS-2014 zostały przez GUS przedstawione w postaci tablic asocjacyjnych, w celu określenia współczynnika skorzystano ze wzoru:

$$
\chi^{2}=\sum_{i=1}^{n} \frac{n(a d-b c)^{2}}{(a+b)(a+c)(b+d)(c+d)}
$$

gdzie użyte symbole określają:

$a$ - liczba jednostek posiadających cechę X i posiadających cechy $\mathrm{Y}$,

$b$ - liczba jednostek posiadających cechę Y i nieposiadających cechy $\mathrm{X}$,

$c$ - liczba jednostek posiadających cechę $\mathrm{X}$ i nieposiadających cechy $\mathrm{Y}$,

$d$ - liczba jednostek nieposiadających żadnej z badanych cech.

Następnie, korzystając ze współczynnika $\varphi$ Yula’a, określono związek dwóch cech, również zapisany w postaci tablic asocjacyjnych, posługując się wzorem:

$$
\varphi=\frac{a d+b c}{\sqrt{(a+b)(a+c)(b+d)(c+d)}}
$$

gdzie symbole odpowiadają zapisanym przy wzorze (1).

Współczynik zastosowany do analizy asocjacji Q-Kendell także został wyznaczony na podstawie tablic ze wzoru:

$$
Q=\frac{a d-b c}{a d+b c}
$$

w celu określenia współczynnika korelacji dla danych prezentowanych w skali nominalnej. 


\section{Aktywność fizyczna związana z uprawianiem sportu}

Aktywność fizyczną w czasie wolnym od pracy czy nauki oceniano na podstawie pytań:

1. Ile razy w tygodniu uprawia Pan/Pani sporty, fitness itp., ćwiczy na siłowni przez co najmniej 10 minut bez przerwy?

2. Ile czasu łącznie spędza Pan/Pani na uprawianiu sportów, fitnessu, rekreacyjnej aktywności fizycznej lub na siłowni w czasie wolnym w zwykłym tygodniu?

3. Przez ile dni w tygodniu wykonuje Pan/Pani ćwiczenia fizyczne na siłowni, to jest ćwiczenia specjalnie opracowane dla wzmocnienia mięśni, na przykład oporowe lub siłowe?

Z analizy opublikowanych niedawno metadanych EHIS-2014 wynika, że w Polsce w czasie wolnym sport, fitness i inną rekreacyjną aktywność fizyczną uprawia 22\% Polaków w wieku 15 lat i więcej (23,4\% mężczyzn i 20,8\% kobiet). Jest to tendencja zaobserwowana już w analizie danych wieloośrodkowego badania reprezentacyjnego WOBASZ, w którym zauważono, że w czasie wolnym sport uprawia większa grupa mężczyzn (27\%) niż kobiet (23\%) (Drygas et al. 2005). Z danych EHIS-2014 wynika, że największy odsetek osób uprawiających aktywność fizyczną był wśród badanych w najmłodszej grupie wiekowej - 15-19 lat (49,3\%), a najmniejszy odsetek w najstarszej grupie wiekowej — 80 lat i więcej $(3,4 \%)$ (zob. rysunek 1).

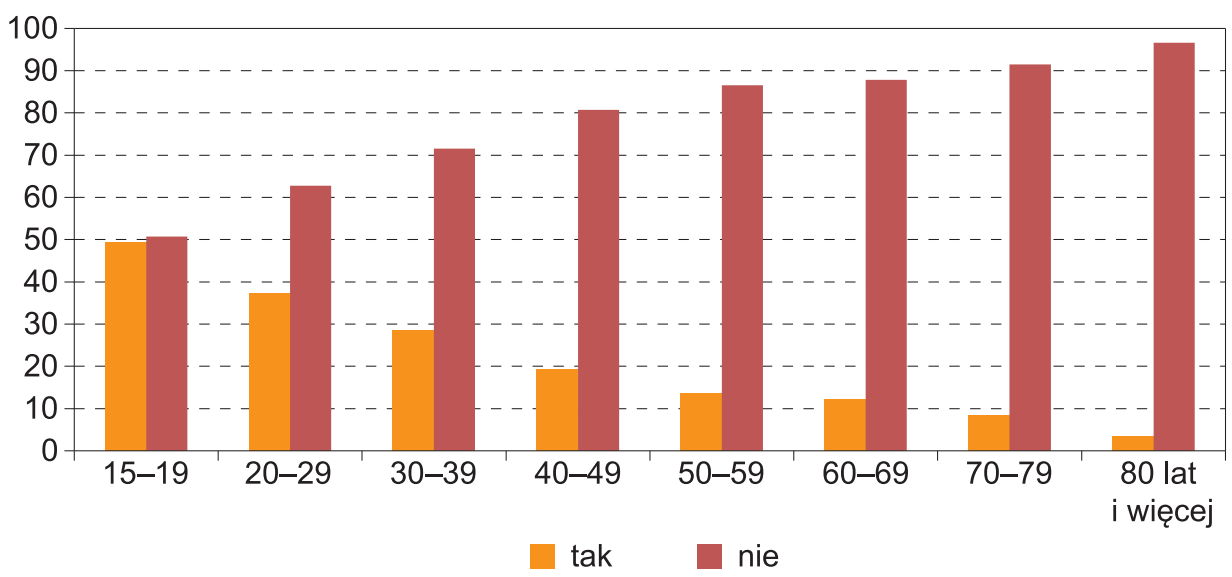

Rysunek 1. Procentowy udział uprawiania aktywności fizycznej w Polsce w przedziale wiekowym

Źródło: opracowanie własne na podstawie GUS 2016.

Wyraźne dysproporcje dla tego rodzaju aktywności fizycznej widać pomiędzy mieszkańcami miast i wsi, ponieważ na wsi tylko $14,5 \%$ mieszkańców uprawia sport, podczas gdy w mieście odestek ten wynosi $26,7 \%$.

Na rysunku 2 widzimy, że w grupie wiekowej 15-19 lat najwięcej osób uprawia sport w czasie wolnym, ćwicząc w zwykłym tygodniu od 60 do 149 minut. 
U Polaków do 39. roku życia, jeśli podejmują oni aktywność fizyczną, przeciętny czas spędzony na ćwiczeniach mieści się $\mathrm{w}$ granicach 60-149 minut.

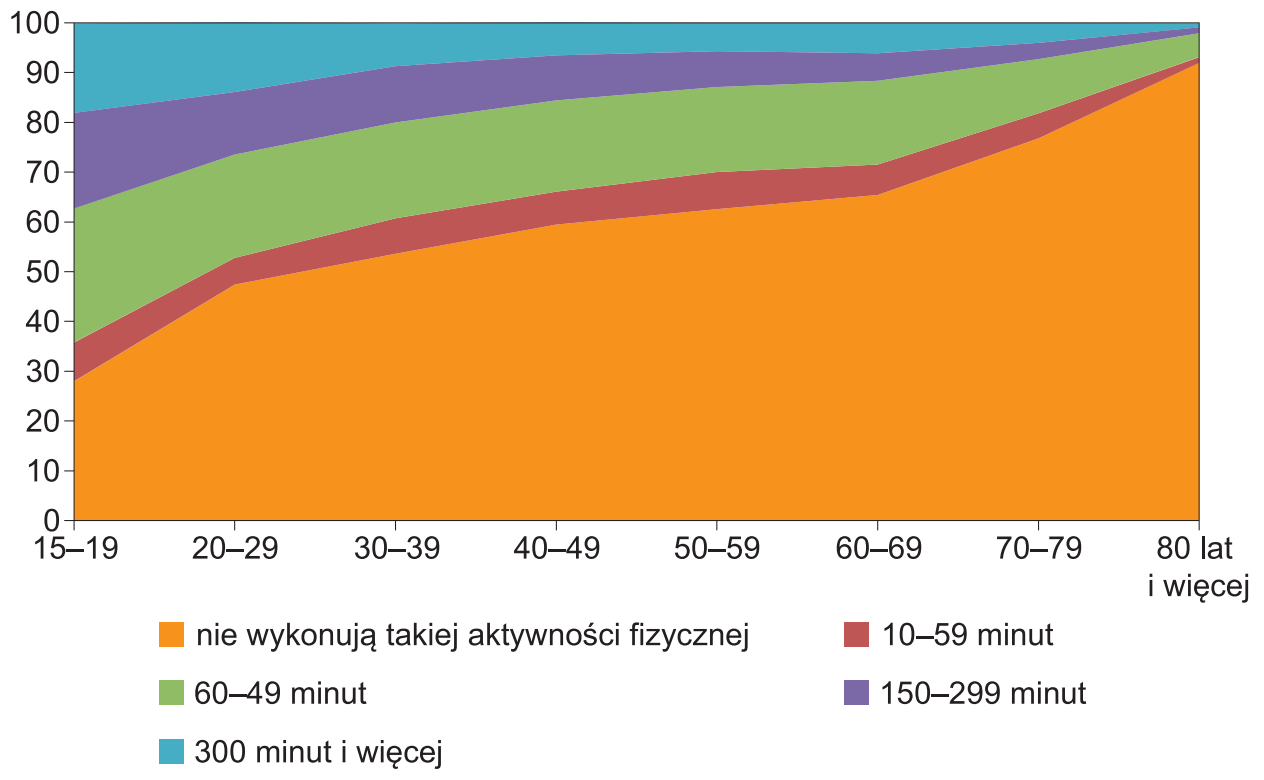

Rysunek 2. Procentowy udział uprawiania aktywności fizycznej w Polsce przez osoby w wieku 15 lat i więcej według czasu w minutach jazdy na rowerze i uprawiania sportów w typowym tygodniu

Źródło: opracowanie własne na podstawie GUS 2016.

Badaniu poddano także relacje między aktywnością fizyczną Polaków a dostępnymi wskaźnikami (SDH) wymienionymi w tabeli 1.

Współczynniki obliczone na podstawie wzorów (1), (2), (3) wskazują na występowanie korelacji pomiędzy wiekiem, wykształceniem i wskaźnikami (SDH) a czasem (w minutach) jazdy na rowerze i uprawianiem sportów w typowym tygodniu, przyjmując właściwą aktywność fizyczną — co najmniej 150 minut tygodniowo (zob. tabela 2).

Tabela 2. Związek między czasem (w minutach) jazdy na rowerze i uprawianiem sportów w typowym tygodniu a społecznymi determinantami zdrowia

\begin{tabular}{l|r|r|r|r|r|c}
\cline { 2 - 7 } & \multicolumn{1}{c|}{$\begin{array}{c}\mathbf{A}- \\
\text { wiek }\end{array}$} & $\begin{array}{c}\text { W- } \\
\text { ziom wyksz- } \\
\text { tałcenia }\end{array}$ & $\begin{array}{c}\text { U - sto- } \\
\text { pień urba- } \\
\text { nizacji }\end{array}$ & $\begin{array}{c}\text { SC - stan } \\
\text { cywilny } \\
\text { faktyczny }\end{array}$ & $\begin{array}{c}\mathbf{R}-\text { status } \\
\text { na rynku } \\
\text { pracy }\end{array}$ & $\begin{array}{c}\mathbf{D} \text { - dochód } \\
\text { ekwiwalentny }\end{array}$ \\
\hline chi kwadrat & 2299,955 & 1436,397 & 364,044 & 258,289 & 181,675 & 197,733 \\
\hline$\varphi$ Yula'a & 0,283 & 0,223 & 0,112 & 0,095 & 0,079 & 0,093 \\
\hline Q-Kendalla & 0,384 & 0,311 & 0,409 & $-0,168$ & 0,123 & $-0,074$ \\
\hline p-value & 0,000 & 0,000 & 0,000 & 0,000 & 0,000 & 0,000 \\
\hline
\end{tabular}

Źródło: opracowanie własne na podstawie GUS 2016.

Ekonomia — Wroclaw Economic Review 23/4 (2017)

(C) for this edition by CNS 
W celu określenia, czy istnieje zależność między czasem (w minutach) jazdy na rowerze i uprawianiem sportów w typowym tygodniu a społecznymi determinantami zdrowia, wykorzystano test dla współczynnika korelacji $\varphi$ Yula’a i Q-Kendalla. Na podstawie otrzymanych wyników p-value o wartości 0,000 (p-value $<0,05$ ) można stwierdzić, że zależność między zmiennymi jest statystycznie istotna.

Starsi, a także niewykształceni respondenci krócej jeżdżą na rowerze i w typowym tygodniu poświęcają mniej czasu na uprawianie sportu od osób młodszych i wykształconych (Ucieklak-Jeż, Bem 2017). Kobiety i mężczyźni w wieku 15 lat i więcej z terenów gęsto zaludnionych (aglomeracje) uprawiają sport częściej, ćwicząc przy tym dłużej. Osoby nieżyjące w związku i pracujące uprawiają „właściwą" aktywność fizyczną. Natomiast przy analizie związku pomiędzy aktywnością fizyczną a dochodem zauważono, że $27 \%$ badanych nie zadeklarowało, w której grupie dochodowej się znajduje. Skutkuje to niemożnością weryfikacji hipotezy mówiącej o tym, że istnieje wyraźny związek pomiędzy dochodem a czasem poświęconym na uprawianie sportu.

\section{Aktywność fizyczna związana z przemieszczaniem się}

W odniesieniu do komunikacyjnej aktywności fizycznej zadawano dwa pytania:

1. Ile razy w tygodniu chodzi Pan/Pani zwykle co najmniej 10 minut bez przerwy, aby dotrzeć do różnych miejsc lub z nich powrócić (nie ujmując chodzenia czy spacerowania dla przyjemności i rekreacji w czasie wolnym)?

2. Jak długo zwykle chodzi Pan/Pani, aby dotrzeć do różnych miejsc i/lub $\mathrm{z}$ nich powrócić $\mathrm{w}$ przeciętnym dniu?

Konsekwentnie przy użyciu dostępnych wskaźników (SDH) wymienionych w tabeli 1 obliczono współczynniki na podstawie wzorów (1), (2), (3) i wskazano na występowanie korelacji statystycznie istotnej pomiędzy wiekiem, wykształceniem, wskaźnikami (SDH) a chodzeniem do różnych miejsc — do pracy, szkoły, sklepu (zob. tabela 3).

Tabela 3. Związek między przemieszczaniem się pieszo w przestrzeni publicznej a społecznymi determinantami zdrowia

\begin{tabular}{l|r|c|c|c|c|c}
\cline { 2 - 7 } & $\begin{array}{c}\mathbf{A} \text { - } \\
\text { wiek }\end{array}$ & $\begin{array}{c}\mathbf{U} \text { - stopień } \\
\text { urbanizacji }\end{array}$ & $\begin{array}{c}\mathbf{W} \text { - poziom } \\
\text { wykształcenia }\end{array}$ & $\begin{array}{c}\text { SC - stan } \\
\text { cywilny } \\
\text { faktyczny }\end{array}$ & $\begin{array}{c}\mathbf{R}-\text { status } \\
\text { na rynku } \\
\text { pracy }\end{array}$ & $\begin{array}{c}\text { D - do- } \\
\text { chód ekwi- } \\
\text { walentny }\end{array}$ \\
\hline chi kwadrat & 1048,395 & 427,903 & 495,514 & 2,458 & 231,464 & 29,391 \\
\hline$\varphi$ Yula'a & 0,190 & 0,128 & 0,131 & 0,017 & 0,089 & 0,036 \\
\hline Q-Kendalla & 0,270 & 0,679 & 0,130 & 0,046 & 0,225 & $-0,072$ \\
\hline p-value & 0,000 & 0,000 & 0,000 & 0,000 & 0,000 & 0,000 \\
\hline
\end{tabular}

Źródło: opracowanie własne na podstawie GUS 2016.

Ekonomia — Wroclaw Economic Review 23/4 (2017)

(C) for this edition by CNS 
Co ciekawe, prawie 85\% Polaków w wieku 15 lat i więcej udaje się pieszo do różnych miejsc — do pracy, szkoły lub na zakupy. Odczytano, że 88,2\% dorosłych przemieszcza się w mieście pieszo, natomiast na wsi odsetek ten wynosi blisko 79,6\%. Starsi oraz niewykształceni respondenci krócej od osób młodszych i wykształconych jeżdżą na rowerze i z mniejszą częstotliwością uprawiają sport w typowym tygodniu. Kobiety i mężczyźni z terenów gęsto zaludnionych (aglomeracji) w wieku 15 lat i więcej częściej przemieszczają się na nogach w przestrzeni publicznej.

Zwiększona częstotliwość przemieszczania się pieszo do pracy, szkoły lub sklepu zaobserwowana w tej grupie osób wynika z konieczności pokonywania mniejszych odległości w terenie zurbanizowanym. Ważną przyczyną poruszania się pieszo niewątpliwie są również korki komunikacyjne w większości miast. Natomiast poruszanie się po terenach wiejskich bez samochodu w celu dotarcia do szkoły lub sklepu odbywa się po drodze lub poboczach, co często staje się przyczyną wypadków. Nie zaskakuje, że starsi niewykształceni mieszkańcy oraz bezrobotni rzadziej przemieszczają się pieszo w przestrzeni publicznej od osób młodszych i wykształconych oraz pracujących.

Średni czas chodzenia Polaków w wieku 15 lat i więcej do różnych miejsc — do pracy, szkoły lub na zakupy (w badanym okresie jesienno-zimowym) wynosi 246,4 minut, z dużym odchyleniem standardowym - 311,1 minut.

\section{Aktywność fizyczna związana z codziennymi czynościami}

Oceny trudności pracy zawodowej dokonywali sami respondenci, odpowiadając na pytanie:

1. Które z poniższych określeń najlepiej opisuje to, co Pan/Pani robi, podczas gdy wykonuje Pan/Pani swoją główną pracę? Czy można powiedzieć, że Pana/ Pani praca jest: głównie siedząca lub stojąca, głównie chodząca lub wymagająca umiarkowanego wysiłku fizycznego, głównie ciężka lub wymagająca znacznego wysiłku fizycznego, nie wykonuję żadnej pracy?

$\mathrm{W}$ ocenie związku pomiędzy aktywnością fizyczną związaną z rodzajem wykonywanej pracy (z podziałem na siedzącą lub stojącą, chodzącą lub wymagającą umiarkowanego wysiłku fizycznego, głównie ciężką lub wymagającą znacznego wysiłku fizycznego) pominięto udział osób, które nie wykonują żadnej pracy. W analizie potraktowano osoby, które wykonują pracę siedzącą lub stojącą, jako niewykonujące aktywności fizycznej (zob. tabela 4).

Również w tym wypadku współczynniki obliczone na podstawie wzorów (1), (2), (3) wskazują na występowanie korelacji statystycznie istotnej pomiędzy wiekiem, wykształceniem i wskaźnikami (SDH). Osoby młodsze, będące w związku formalnym, pracują ciężej, czyli podczas pracy są aktywni fizycznie, z wiekiem natomiast aktywność fizyczna w pracy maleje. Natomiast mieszkańcy terenów 
mniej zurbanizowanych są bardziej aktywni fizycznie. Co więcej, bezrobotni lub bierni zawodowo nie wykonują pracy i nie zgłaszają aktywności fizycznej w pracy.

Z kolei osoby deklarujące dochód w I i II grupie kwintylowej w trakcie pracy są bardziej aktywni fizycznie od mieszkańców z dochodami w III, IV i V grupie kwintylowej.

Tabela 4. Związek między aktywnością fizyczną związaną z wykonywaniem pracy a społecznymi determinantami zdrowia

\begin{tabular}{l|r|r|r|r|r|r}
\cline { 2 - 7 } & $\begin{array}{c}\mathbf{W} \text { - } \\
\text { wiek }\end{array}$ & $\begin{array}{c}\text { U-stopień } \\
\text { urbanizacji }\end{array}$ & $\begin{array}{c}\mathbf{W} \text { - poziom } \\
\text { wykształcenia }\end{array}$ & $\begin{array}{c}\text { SC - stan } \\
\text { cywilny } \\
\text { faktyczny }\end{array}$ & $\begin{array}{c}\mathbf{R} \text { - status } \\
\text { na rynku } \\
\text { pracy }\end{array}$ & $\begin{array}{c}\text { D - do- } \\
\text { chód ekwi- } \\
\text { walentny }\end{array}$ \\
\hline chi kwadrat & 9557,031 & 790,066 & 2310,092 & 554,587 & 2351,883 & 19070,627 \\
\hline$\varphi$ Yula'a & 0,752 & 0,166 & 0,304 & 0,139 & 0,286 & 1,431 \\
\hline Q-Kendalla & 0,164 & $-0,270$ & $-0,641$ & 0,278 & 0,192 & 0,253 \\
\hline p-value & 0,000 & 0,000 & 0,000 & 0,000 & 0,000 & 0,000 \\
\hline
\end{tabular}

Źródło: opracowanie własne na podstawie GUS 2016.

\section{Aktywność fizyczna a zdrowie Polaków}

Podjęto próbę zbadania zależności pomiędzy aktywnością fizyczną a oceną stanu zdrowia, długotrwałymi problemami zdrowotnymi, chorobami i dolegliwościami przewlekłymi oraz sprawnością.

Tabela 5. Udział procentowy mieszkańców Polski a ocena stanu zdrowia, długotrwałe problemy zdrowotne, choroby i dolegliwości przewlekłe oraz sprawność

\begin{tabular}{|c|c|c|c|}
\hline \multirow{2}{*}{ Stan zdrowia } & \multicolumn{2}{|c|}{ Uprawia sport } & \multirow{2}{*}{$\begin{array}{c}\text { Nie uprawia } \\
\text { sportu }\end{array}$} \\
\hline & fitness, ćwiczenia & siłownia & \\
\hline \multicolumn{4}{|l|}{ Ocena stanu zdrowia } \\
\hline bardzo dobre i dobre & 17,2 & 10,9 & 71,9 \\
\hline takie sobie - ani dobre, ani złe & 11,2 & 3,0 & 85,8 \\
\hline złe i bardzo złe & 6,1 & 0,6 & 93,3 \\
\hline \multicolumn{4}{|l|}{ Długotrwałe problemy zdrowotne } \\
\hline z problemami zdrowotnymi & 13,4 & 4,8 & 81,8 \\
\hline bez problemów zdrowotnych & 15,6 & 11,4 & 73,0 \\
\hline \multicolumn{4}{|l|}{ Choroby i dolegliwości przewlekle } \\
\hline chorujący przewlekle & 13,5 & 4,9 & 81,6 \\
\hline niechorujący przewlekle & 15,6 & 11,6 & 72,8 \\
\hline \multicolumn{4}{|l|}{ Sprawność } \\
\hline niesprawni & 8,5 & 1,5 & 90,0 \\
\hline sprawni & 15,2 & 8,7 & 76,1 \\
\hline
\end{tabular}

Źródło: opracowanie własne na podstawie GUS 2016.

Ekonomia — Wroclaw Economic Review 23/4 (2017)

(C) for this edition by CNS 
Brak aktywności fizycznej obserwowany był również wśród osób cieszących się dobrym stanem zdrowia (osoby oceniające swoje zdrowie jako bardzo dobre lub dobre czy też osoby bez długotrwałych problemów zdrowotnych lub niechorujące przewlekle).

Tabela 6. Związek między aktywnością fizyczną a oceną stanu zdrowia i podziałem na grupy społeczne populacji, to jest z długotrwałymi problemami zdrowotnymi, chorymi przewlekle i z dolegliwościami przewlekłymi oraz sprawnych

\begin{tabular}{l|r|c|c|c}
\cline { 2 - 5 } & $\begin{array}{c}\text { SZ _ stan } \\
\text { zdrowia }\end{array}$ & $\begin{array}{c}\text { DPZ - długotrwałe } \\
\text { problemy zdrowotne }\end{array}$ & $\begin{array}{c}\text { CHDP - choroby } \\
\text { i dolegliwości } \\
\text { przewlekle }\end{array}$ & $\begin{array}{c}\text { S - } \\
\text { sprawność }\end{array}$ \\
\hline chi kwadrat & 1268,279 & 1015,488 & 505,240 & 437,606 \\
\hline$\varphi$ Yula'a & 0,208 & 0,198 & 0,131 & 0,122 \\
\hline Q-Kendalla & 0,633 & 0,393 & 0,249 & 0,478 \\
\hline współczynnik gamma & 0,449 & 0,342 & 0,213 & 0,447 \\
\hline p-value & 0,000 & 0,000 & 0,000 & 0,000 \\
\hline
\end{tabular}

Źródło: opracowanie własne na podstawie GUS 2016.

W przypadku relacji między aktywnością fizyczną a oceną stanu zdrowia przez osoby z długotrwałymi problemami zdrowotnymi, chorobą i dolegliwościami przewlekłymi oraz sprawnością istnieje związek korelacyjny statystycznie istotny — osoby uprawiające sport cieszą się bowiem lepszym zdrowiem. Częściej aktywnymi miszkańcami Polski są osoby bez długotrwałych problemów zdrowotnych, a także bez chorób przewlekłych i sprawni.

Literatura wskazuje, że wraz z wiekiem znacząco wzrasta zagrożenie niepełnosprawnością związaną z niemożnością prowadzenia aktywnego życia. Choroby przewlekłe i zaburzenia psychiczne są jednym z podstawowych czynników obniżających tę sprawność (Kondo et al. 2008), przy czym, w świetle badań, obciążenie niepełnosprawnością jest wyższe w odniesieniu do kobiet niż mężczyzn (Andrade et al. 2011; Lunenfeld, Stratton 2013).

\section{Zakończenie}

Dane uzyskane w Europejskim Ankietowym Badaniu Zdrowia (EHIS-2014) wskazują, że struktura zbadanej populacji nie odbiega znacząco od struktury ludności według Narodowego Spisu Powszechnego Ludności i Mieszkań (NSP) 2011, a otrzymane i przedstawione wyniki oraz wnioski zaprezentowane w artykule uprawniają do odniesienia ich także do mieszkańców Polski.

W pracy zweryfikowano i przeanalizowano związki między:

— czasem jazdy na rowerze (w minutach) i uprawianiem sportów w typowym tygodniu a społecznymi determinantami zdrowia,

— przemieszczaniem się pieszo w przestrzeni publicznej a społecznymi determinantami zdrowia, 
— aktywnością fizyczną związaną z wykonywaniem pracy a społecznymi determinantami zdrowia,

— aktywnością fizyczną a oceną stanu zdrowia, długotrwałymi problemami zdrowotnymi, chorobami i dolegliwościami przewlekłymi oraz sprawnością.

Hipoteza pierwsza została zweryfikowana pozytywnie — otóż mieszkańcy dużych miast często bardzo wiele czasu spędzają w pracy, są zestresowani i potrzebują ruchu. Korporacje w celu zapewnienia i poprawy komfortu pracy fundują swoim pracownikom zajęcia sportowo-relaksacyjne lub zapewniają sale treningowe w miejscu pracy. Jednakże brak aktywności zaobserwowano także u osób cieszących się dobrym stanem zdrowia. Wśród Polaków brakuje jeszcze nawyku aktywnego życia, zarówno wśród młodych, jak i starszych osób.

Hipoteza druga została zweryfikowana tylko częściowo - chi kwadrat: 1692,469; $\varphi$ Yula'a: 0,322; Q-Kendalla: 0,297; istnieje zależność statystycznie istotna pomiędzy ilością czasu poświęconego na uprawianie sportu a zdrowiem. Im jest on dłuższy, tym lepsze zdrowie. W badaniu zakładano analizę trzech rodzajów aktywności fizycznej, nie uwzględniano jednak ogólnego czasu aktywności. Z tego względu nie możemy wnioskować, jaki czas aktywności fizycznej —o średniej intensywności — da Polakom przepustkę do zdrowia.

Hipoteza trzecia została zweryfikowana pozytywnie — aktywni fizycznie cieszą się lepszym zdrowiem. Uprawianie sportu powinno odbywać się przez całe życie i być traktowane jako naturalna czynność zapewniająca poprawne funkcjonowanie organizmu. Aktywność fizyczna dostosowana do indywidualnych potrzeb ma zdecydowanie korzystny wpływ na zdrowie.

\section{Bibliografia}

Andrade F.C.D. et al. (2011), Gender differences in life expectancy and disability-free life expectancy among older adults in Sao Paulo, Brazil, „Women's Health Issues” 21, nr 1, s. 64-70.

Andrade F.C.D. et al. (2014), Life expectancy with and without cognitive impairment among Brazilian older adults, ,Archives of Gerontology and Geriatrics” 58, nr 2, s. 219-225.

Broszkiewicz M., Drygas W. (2016), Potrzeba wdrożenia w Polsce nowych narzędzi do diagnozowania zespołu uzależnienia od tytoniu oraz gotowości i motywacji do rzucenia palenia u osób w wieku produkcyjnym, „Medycyna Pracy” 67, nr 1, s. 97-108.

Brown W.J., Burton N.W., Rowan P.J. (2007), Updating the evidence on physical activity and health in women, „American Journal of Preventive Medicine” 33, nr 5, s. 404-411.

Brown W.J., Hockey R., Dobson A.J. (2008), Physical activity, Body Mass Index and health care costs in mid-age Australian women, „Australian and New Zealand Journal of Public Health” 32 , nr 2, s. 150-155.

Bucksch J., Schlicht W. (2006), Health-enhancing physical activity and the prevention of chronic diseases - an epidemiological review, „Sozial-und Präventivmedizin/Social and Preventive Medicine" 51, nr 5, s. 281-301.

Cockerham W.C. (2000), Health lifestyles in Russia, „Social Science \& Medicine” 51, nr 9, s. $1313-$ 1324. 
Cuesta H.M., Calle P.A. (2013), Benefits of exercise in healthy population and impact on disease occurrence, „Endocrinología y nutrición: órgano de la Sociedad Española de Endocrinología y Nutrición" 60, nr 6, s. 283.

Dalton B. et al. (2015), Australian indigenous youth's participation in sport and associated health outcomes: Empirical analysis and implications, „Sport Management Review” 18, s. 57-68.

Drygas W., Jegier A. (2003), Zalecenia dotyczace aktywności ruchowej w profilaktyce chorób układu krążenia, „Czynniki Ryzyka” 38/39, s. 76-84, http://www.umed.edu.pl/geriatria/pdf/ Zalecenia_dotyczace_aktywnosci_ruchowej_w_profilaktyce_chorob_ukladu_krazenia.pdf (dostęp: 1.05.2018).

Drygas W. et al. (2005), Ocena poziomu aktywności fizycznej dorostej populacji Polski. Wyniki programu WOBASZ, „Kardiologia Polska (Polish Heart Journal)” 63, nr 4, s. 1-5.

Eime R.M. et al. (2013), A systematic review of the psychological and social benefits of participation in sport for children and adolescents: informing development of a conceptual model of health through sport, „International Journal of Behavioral Nutrition and Physical Activity” 10, nr 1, s. 98.

Evenson K. (2002), Vigorous leisure activity through women's adult life: The Women's Health Initiative Observational Cohort Study, „American Journal of Epidemiology” 10, s. 945-953.

Gremeaux V. et al. (2012), Exercise and longevity, „Maturitas” 73, s. 312-317.

GUS (2016), Stan zdrowia ludności w 2014 r., Warszawa.

Hanlon C., Morris T., Nabbs S. (2010), Establishing a successful physical activity program to recruit and retain women, „Sport Management Review” 13, nr 3, s. 269-282.

Hernández M.C., Pascual A.L.C. (2013), Beneficios del ejercicio físico en población sana e impacto sobre la aparición de enfermedad, „Endocrinología y nutrición: órgano de la Sociedad Española de Endocrinología y Nutrición” 60, nr 6, s. 283-286.

Hunter R. et al. (2015), Addressing inequalities in physical activity participation: Implications for public health policy and practice, „Preventive Medicine” marzec, s. 64-69.

Inoue M. et al. (2008), Daily total physical activity level and premature death in men and women: Results from a large-scale population-based cohort study in Japan (JPHC study), „Annals of Epidemiology" 18, nr 7, s. 522-530.

Kondo N. et al. (2008), Impact of mental health on daily living activities of Japanese elderly, „Preventive Medicine" 46, nr 5, s. 457-462.

Lee C. (1993), Factors related to the adoption of exercise among older women, „Journal of Behavioral Medicine" 16, nr 3, s. 323-334.

Lee I.M. et al. (2012), Effect of physical inactivity on major non-communicable diseases worldwide: An analysis of burden of disease and life expectancy, „Lancet” 308, s. 219-229.

Lunenfeld B., Stratton P. (2013), The clinical consequences of an ageing world and preventive strategies, „Best Practice \& Research” 27, s. 643-659.

McFadden E. et al. (2008), Social inequalities in self-rated health by age: Cross-sectional study of 22457 middle-aged men and women, ,BMC Public Health” 8, nr 1, s. 230.

Milne M. et al. (2014), Non-participation: How age influences inactive women's views of exercise, „Journal of Applied Biobehavioral Research” 19, nr 3, s. 171-191.

Ostrowska A. (1999), Styl życia a zdrowie, Warszawa.

Puciato D. et al. (2013), Aktywność fizyczna dorostych mieszkańców Katowic a wybrane uwarunkowania zawodowe i społeczno-ekonomiczne, „Medycyna Pracy” 64, nr 5, s. 649-657.

Rodríguez-Fuentes G. et al. (2014), An observational study on the effects of Pilates on quality of life in women during menopause, „European Journal of Integrative Medicine” 6 (6), s. 631-636.

Roux L. et al. (2008), Cost effectiveness of community-based physical activity interventions, „American Journal of Preventive Medicine” 35, nr 6, s. 578-588.

Ekonomia — Wroclaw Economic Review 23/4 (2017)

(C) for this edition by CNS 
Sari N. (2011), Exercise, physical activity and healthcare utilization: A review of literature for older adults, ,Maturitas” 70, nr 3, s. 285-289.

Simons D. et al. (2015), Psychosocial moderators of associations between life events and changes in physical activity after leaving high school, „Preventive Medicine” 72, s. 30-33.

Slater A., Tiggemann M. (2011), Gender differences in adolescent sport participation, teasing, selfobjectification and body image concerns, ,Journal of Adolescence” 34, s. 455-463.

Svedberg P. et al. (2006), A prospective study of health, life-style and psychosocial predictors of self-rated health, „European Journal of Epidemiology” 21, nr 10, s. 767-776.

Ucieklak-Jeż P. (2016a), Education and income as health determinants in Central-Eastern Europe, „Prace Naukowe Akademii im. Jana Długosza w Częstochowie. Pragmata tes Oikonomias” 10, s. 171-184.

Ucieklak-Jeż P. (2016b), Health inequality determined by education and income in European countries, „Prace Naukowe Akademii im. Jana Długosza w Częstochowie. Pragmata tes Oikonomias" 10 , s. 157-170.

Ucieklak-Jeż P., Bem A. (2015), Women's physical activity as a determinant of health care expenditures, „Prace Naukowe Akademii im. Jana Długosza w Częstochowie. Pragmata tes Oikonomias" 9, s. 173-188.

Ucieklak-Jeż P., Bem A. (2017), Wiek i płeć jako czynnik wptywający na subiektywna jakość życia osób starszych, [w:] Zdrowie dla regionu, red. E. Lorc, K. Plewa-Tukaj, Wałbrzych 2017, s. $165-180$.

Uijtdewilligen L. et al. (2015), Determinants of physical activity in a cohort of young adult women. Who is at risk of inactive behaviour?, „Journal of Science and Medicine in Sport” 18, nr 1, s. $49-55$.

Warburton D.E. et al. (2010), A systematic review of the evidence for Canada's Physical Activity Guidelines for Adults, „International Journal of Behavioral Nutrition and Physical Activity” 7.

Warburton D.E., Nicol C.W., Bredin S.S. (2006), Health benefits of physical activity: The evidence, „Canadian Medical Association Journal” 174, nr 6, s. 801-809.

Wróblewska W. (2002), Determinants of women's health status in Poland in transition to market economy, „Social Science and Medicine” 54, nr 5, s. 707-726.

Wróblewska W. (2010), Stan zdrowia w Polsce - rola czynników ekonomiczno-społecznych i stylu życia. Ocena na podstawie wskaźnika SRH i PAR. „Zeszyty Naukowe Instytut Statystyki i Demografii SGH”2, Warszawa.

Ekonomia — Wroclaw Economic Review 23/4 (2017)

(C) for this edition by CNS 